\title{
RAISED IgG ANTIGLOBULIN FACTORS IN STILL'S DISEASE
}

\author{
BY \\ G. TORRIGIANI, ${ }^{1}$ B. M. ANSELL, ${ }^{2}$ E. E. A. CHOWN, ${ }^{1}$ AND I. M. ROITT ${ }^{1}$ \\ From the Department of Immunology, ${ }^{1}$ Middlesex Hospital Medical School, London, and the \\ M.R.C. Rheumatism Unit, ${ }^{2}$ Canadian Red Cross Memorial Hospital, Taplow, Maidenhead, Berks
}

Still's disease (juvenile chronic polyarthritis) differs markedly from adult rheumatoid arthritis in the relative incidence of rheumatoid factor. The sheep cell agglutination test was found to be positive in only 11 to 13 per cent. of Still's disease patients compared with 70 to 80 per cent. of affected adults (Bywaters, Carter, and Scott, 1959; Laaksonen, 1966). Similarly, using the sensitive agglutination test with human FII coated erythrocytes, only 26 per cent. of definite cases of Still's disease gave titres of 1: 200 or more in contrast with an incidence of 87 per cent. in cases of classical and definite rheumatoid arthritis (Zutshi, Ansell, Bywaters, Epstein, Holborrow, and Reading, 1969).

Since antibodies of the IgM class tend to be particularly effective in agglutination reactions, it is likely that the conventional tests for rheumatoid factor minimize any possible contribution from antiglobulin factors in other immunoglobulin classes. Accordingly, we have recently developed a technique for the quantitative assessment of antiglobulin factors in the $\operatorname{IgG}, \operatorname{IgM}$, and $\operatorname{IgA}$ classes (Torrigiani and Roitt, 1967). The method depends upon the adsorption of antiglobulins on to insoluble crosslinked rabbit $\gamma$-globulin, their subsequent elution from this complex, and estimation by single radial immunodiffusion using specific anti-immunoglobulin antisera. It was found that in addition to IgM antiglobulin factors, IgA antibodies were present in 50 per cent. and IgG antiglobulins in 100 per cent. of sero-positive adult rheumatoid arthritis patients. In the present investigation we have looked for antiglobulin factors in the sera of children with Still's disease using this quantitative technique.

\section{Material and Methods}

Clinical Material.-This consisted of 35 cases of Still's disease, 26 classified as active (Ansell and Bywaters, 1959) and nine as inactive (Table, opposite).
Active Cases.-Seven were males and their ages at the time of testing ranged from 5 to 17 years and the duration of disease from 8 months to 9 years. Nineteen were female and their ages at the time of testing ranged from 3 to 19 years, and the duration of the disease from 4 months to 10 years.

In two patients (Cases 6 and 25) the disease was confined to the knee, and in both the histology of the synovial membrane was characteristic of rheumatoid arthritis. Two patients (Cases 14 and 19) were suffering from chronic iridocyclitis in addition to widespread joint involvement, one (Case 16) had developed psoriasis, and one (Case 23) amyloidosis (Table). All patients with active disease were receiving salicylates; in addition five were receiving $\mathrm{ACTH}$, seven prednisone, and seven myocrisin.

Inactive Cases.-Two were male and their ages were 17 and 23 years; both showed residua from their disorder but were able to lead normal lives. Of the seven girls, four aged from 17 to 24 years were in complete remission though all showed residua of their previous disease. Two younger girls, aged 8 and 13 years, had only just become inactive, and one older girl (aged 24) whose disease was inactive had been in hospital for surgery on one wrist; all three were still receiving small doses of aspirin.

Controls. - These consisted of five boys aged from $4 \frac{1}{2}$ to 9 years and five girls aged from $2 \frac{1}{2}$ to 14 years who were completely well. In addition there were eight sick male controls aged from 3 to 10 years with a variety of conditions including infections; two had osteomyelitis, two urinary tract infections, and two upper respiratory tract infections, while one had a neuroblastoma and another congenital heart disease. Among seven girls classed as sick controls, there was one with urinary infection, two had recovered from pneumonia, one was suffering from hypoglycaemia, one had growth retardation, and two had congenital heart disease.

\section{Antisera}

(a) Antisera to human IgG were prepared in rabbits by intramuscular injection of $5-10 \mathrm{mg}$. human Fc (Porter, 1959) in complete Freund's adjuvant followed by 
TABLE

ANTIGLOBULIN TESTS IN STILL'S DISEASE

\begin{tabular}{|c|c|c|c|c|c|c|c|c|c|}
\hline \multirow{2}{*}{ Class } & \multirow{2}{*}{ Case No. } & \multirow{2}{*}{ Sex } & \multirow{2}{*}{$\underset{\text { (yrs) }}{\text { Age }}$} & \multicolumn{3}{|c|}{ Antiglobulins ( $\mu \mathrm{g} . / \mathrm{ml})}$. & \multirow{2}{*}{ DAT } & \multirow{2}{*}{ Latex } & \multirow{2}{*}{ Comment } \\
\hline & & & & IgG & IgA & IgM & & & \\
\hline & $\begin{array}{l}1 \\
2 \\
3 \\
4 \\
5 \\
6 \\
7\end{array}$ & $\begin{array}{l}\mathbf{M} \\
\mathbf{M} \\
\mathbf{M} \\
\mathbf{M} \\
\mathbf{M} \\
\mathbf{M} \\
\mathbf{M}\end{array}$ & $\begin{array}{r}5 \\
17 \\
7 \\
13 \\
12 \\
9 \\
14\end{array}$ & $\begin{array}{r}111 \\
71 \\
61 \\
68 \\
49 \\
56 \\
86\end{array}$ & $\begin{array}{l}a \\
- \\
- \\
- \\
-\end{array}$ & $\begin{array}{l}36 \\
= \\
= \\
=\end{array}$ & $\begin{array}{l}E \\
\bar{E} \\
-\end{array}$ & $\begin{array}{l}= \\
\text { E } \\
=\end{array}$ & Monarticular \\
\hline Active & $\begin{array}{r}8 \\
9 \\
10 \\
11 \\
12 \\
13 \\
14 \\
15 \\
16 \\
17 \\
18 \\
19 \\
20 \\
21 \\
22 \\
23 \\
24 \\
25 \\
26\end{array}$ & $\begin{array}{l}\mathbf{F} \\
\mathbf{F} \\
\mathbf{F} \\
\mathbf{F} \\
\mathbf{F} \\
\mathbf{F} \\
\mathbf{F} \\
\mathbf{F} \\
\mathbf{F} \\
\mathbf{F} \\
\mathbf{F} \\
\mathbf{F} \\
\mathbf{F} \\
\mathbf{F} \\
\mathbf{F} \\
\mathbf{F} \\
\mathbf{F} \\
\mathbf{F} \\
\mathbf{F}\end{array}$ & $\begin{array}{r}7 \\
9 \\
7 \\
6 \\
10 \\
19 \\
10 \\
14 \\
10 \\
12 \\
7 \\
5 \\
15 \\
14 \\
15 \\
13 \\
8 \\
3 \\
8\end{array}$ & $\begin{array}{r}68 \\
96 \\
55 \\
200 \\
73 \\
49 \\
64 \\
87 \\
43 \\
113 \\
89 \\
89 \\
82 \\
48 \\
41 \\
46 \\
116 \\
77 \\
111\end{array}$ & $\begin{array}{l}= \\
\overline{10} \\
10 \\
= \\
\overline{5} \\
= \\
= \\
= \\
= \\
= \\
-\end{array}$ & $\begin{array}{l}18 \\
\bar{Z} \\
54 \\
\overline{-} \\
\overline{64} \\
\overline{27} \\
\bar{Z} \\
\bar{Z} \\
\bar{Z} \\
\bar{Z} \\
161\end{array}$ & $\begin{array}{c}= \\
\bar{Z} \\
1: 16 \\
\bar{z} \\
1: 256 \\
1: 32 \\
= \\
= \\
= \\
= \\
=\end{array}$ & 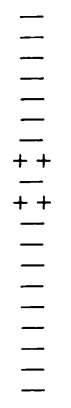 & $\begin{array}{l}\text { Iridocyclitis } \\
\text { Psoriasis } \\
\text { Iridocyclitis } \\
\text { Amyloidosis } \\
\text { Monarticular }\end{array}$ \\
\hline \multirow{4}{*}{ Inactive } & $\begin{array}{l}27 \\
28\end{array}$ & $\begin{array}{l}\mathbf{M} \\
\mathbf{M}\end{array}$ & $\begin{array}{l}17 \\
23\end{array}$ & $\begin{array}{l}16 \\
22\end{array}$ & - & - & - & $-\}$ & Normal lives \\
\hline & $\begin{array}{l}29 \\
30 \\
31 \\
32\end{array}$ & $\begin{array}{l}\mathbf{F} \\
\mathbf{F} \\
\mathbf{F} \\
\mathbf{F}\end{array}$ & $\begin{array}{l}24 \\
22 \\
23 \\
17\end{array}$ & $\begin{array}{l}25 \\
17 \\
22 \\
17\end{array}$ & $\underline{-}$ & E & E & $\begin{array}{l}- \\
- \\
-\end{array}$ & $\begin{array}{l}\text { Complete } \\
\text { remission }\end{array}$ \\
\hline & $\begin{array}{l}33 \\
34\end{array}$ & $\begin{array}{l}\mathbf{F} \\
\mathbf{F}\end{array}$ & $\begin{array}{r}13 \\
8\end{array}$ & $\begin{array}{l}58 \\
33\end{array}$ & - & - & - & $-\}$ & $\begin{array}{l}\text { Recent } \\
\text { remission }\end{array}$ \\
\hline & 35 & $\mathbf{F}$ & 24 & 176 & 15 & 23 & - & - & Wrist surgery \\
\hline
\end{tabular}

$a$; IgA and $\operatorname{IgM}<10 \mu \mathrm{g} . / \mathrm{ml}$.; DAT $<1: 16$; Latex $<1: 20$.

by $5 \mathrm{mg}$. alum precipitated antigen given as five intravenous injections over the 4th and 5th weeks; the animals were bled after a further week. The resulting antisera were made specific for human IgG by absorption with Bence Jones proteins of both $\kappa$ and $\lambda$ types.

(b) Antisera to human IgA were raised in rabbits by injecting an IgA myeloma protein prepared from serum by Pevikon block electrophoresis. The immunization schedule was similar to that used for the preparation of anti-IgG. The antisera were made specific for IgA by absorption with serum from cord blood and a preparation of IgM (see below).

(c) Antisera to human IgM were prepared in a similar way to anti-IgG. The IgM used for immunization was obtained from the serum of a patient with Waldenström's macroglobulinaemia by fractionation of the euglobulin fraction on Sephadex G200. The antisera were absorbed with serum from cord blood and IgA myeloma protein.

All the antisera after absorption were specific for the corresponding immunoglobulin class as judged by immunoelectrophoresis.

Rheumatoid Factor Tests.-The differential agglutination test (DAT) and the latex-fixation test as described by Bywaters and Scott (1960) were carried out on all samples of serum.

Quantitative Immunoadsorption of Antiglobulins.Insoluble cross-linked rabbit Cohn fraction II was prepared as described by Torrigiani and Roitt (1967). $20 \mathrm{mg}$. insoluble rabbit Cohn fraction II suspended in $1 \mathrm{ml}$. phosphate buffered saline $\mathrm{pH} 7 \cdot 2$ was incubated at $37^{\circ} \mathrm{C}$. for $1 \mathrm{hr}$. with $0.25 \mathrm{ml}$. serum and left at $4^{\circ} \mathrm{C}$. overnight. This procedure was found to absorb rheumatoid factor completely from sera giving high titres in the sheep cell agglutination test.

The polymerized antigen was spun and washed five times with cold 0.9 per cent. saline. The sediment was resuspended in $0.5 \mathrm{ml} .0 \cdot 1 \mathrm{M}$ glycine- $\mathrm{HCl}$ buffer $\mathrm{pH} 2 \cdot 5$, at $4^{\circ} \mathrm{C}$. After $1 \mathrm{hr}$. the mixture was spun and the supernatant brought near to neutrality by addition of $0.03 \mathrm{ml}$. $0.5 \mathrm{~N} \mathrm{NaOH}$. The amount of antiglobulin in each of the major immunoglobulin classes was determined by single radial immunodiffusion using specific antisera (Mancini, Carbonara, and Heremans, 1965). The results were corrected to allow for dilution due to the liquid retained in the washed pellet before addition of the acid buffer. This dilution factor was found to be about 15 per cent. with the preparation of insoluble antigen used in the test. The validity of this method for the 
estimation of antibody has been discussed elsewhere (Torrigiani and Roitt, 1969).

\section{Results}

Controls.-The children in the control group all gave values for IgG antiglobulin lying within the range 14 to $31 \mu \mathrm{g} . / \mathrm{ml}$. serum (Figure). Tests for IgA and IgM antiglobulins were negative, except for one case with $2 \cdot 7 \mu \mathrm{g}$. IgA antiglobulin $/ \mathrm{ml}$. and $151 \mu \mathrm{g} . \mathrm{IgM} / \mathrm{ml}$., in whom the diagnosis was uncertain. These results are similar to those obtained with a group of normal adult subjects (14 to 33 $\mu \mathrm{g} . / \mathrm{ml}$.).

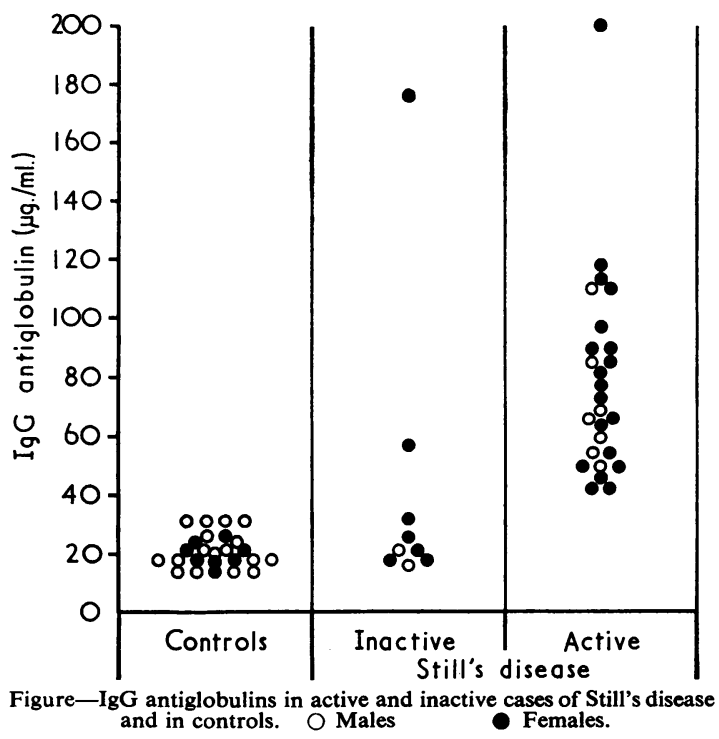

Active Cases.-In the group of 26 children with active Still's disease, the IgG antiglobulins were consistently raised (Table). They ranged from 41 to $200 \mu \mathrm{g} . / \mathrm{ml}$. and there was no overlap with the controls (Figure). There was no difference between the values obtained for males and females. Three sera contained minimal concentrations of $\operatorname{IgA}$ antiglobulin. Despite the fact that only three cases were positive in the DAT and latex tests, a total of seven sera had detectable IgM antiglobulins. One of these sera (Table; Case 26) giving negative agglutination tests, had the hich IgM antiglobulin value of $161 \mu \mathrm{g} . / \mathrm{ml}$.

Inactive Cases.-Of the nine cases of inactive Still's studied, all but two had low concentrations of IgG antiglobulin. Of these two, one examined 5 weeks after surgery for fusion of the wrist (Case 35) also had detectable IgA and IgM antiglobulin and subsequently had mild symptoms in other joints; the other (Case 33) presented no unusual clinical features at the time of study but had a recurrence of soft tissue swelling of one knee following minor injury 18 months later.

\section{Discussion}

The clear-cut finding of raised levels of IgG antiglobulins in children with active Still's disease may be of help in diagnosis. Values for controls which included children with acute infections were far lower and there was no overlap between the two groups. Most of the inactive cases gave results falling in the normal range, but two were raised and both have shown a recurrence of symptoms. These results suggest that the test may be a useful indicator of disease activity.

These results contrast with the relatively low incidence of antiglobulins in Still's disease revealed by conventional agglutination tests for rheumatoid factor. The reason for this cannot be ascribed entirely to the lower agglutinating potency of IgG as against IgM antibody, since some sera had appreciable concentrations of IgM antiglobulins and yet were negative in the DAT and latex tests. Furthermore, preliminary experiments showed that the IgG antiglobulins could not be absorbed out with heat-aggregated rabbit $\gamma$-globulin as was the case with classical rheumatoid factors. It must be presumed therefore that the antiglobulins in Still's disease react with a different determinant on the rabbit IgG revealed during the cross-linking with bis-diazobenzidine.

The universal presence of antiglobulins in the childhood disorder provides evidence for the view that the disease mechanisms are similar to those occurring in adult arthritis, where even "seronegative" patients have raised antiglobulins as revealed by the quantitative immunoadsorption technique (Torrigiani, Corbett, Lloyd, and Roitt, 1969). These antibodies are thought to arise either as a reaction to continued formation of immune complexes which lead to configurational changes in the host IgG, or perhaps to a cross-reaction between IgG and antigens present in as yet unidentified micro-organisms considered to be responsible for initiating the disease. The differences observed in the specificity and class of the antiglobulins in Still's disease could be related to differences in the antigens responsible for their formation. 


\section{Summary}

IgG antiglobulins measured by a quantitative immunoadsorption technique were raised in all of 26 cases of active Still's disease. Only two out of nine classed as inactive showed raised values and these have both subsequently had recurrence of soft tissue swelling. Four active cases had IgM antiglobulins but negative DAT and latex tests.
We thank Mr. A. Reading for performing the DAT and latex tests and Mrs. G. Stead for help in preparation of the manuscript. G.T. is the holder of a Wates' Fellowship. The work was supported by grants from the Arthritis and Rheumatism Council, the Nuffield Foundation, and the World Health Organization.

\section{REFERENCES}

Ansell, B. M., and Bywaters, E. G. L. (1959). Bull rheum. Dis., 9, 189 (Prognosis in Still's disease). Bywaters, E. G. L., Carter, M. E., and Scott, F. E. T. (1959). Ann. rheum. Dis., 18, 225 (Differential agglutination titre (DAT) in juvenıle rheumatoid arthritis).

- and Scott, F. E. T. (1960). "Rheumatism and connective tissue disorders", in "Recent Advances in Clinical Pathology", ed. S. C. Dyke. Churchill, London.

Laaksonen, A. L. (1966). Acta pediat. scand., Suppl. 166 (A prognostic study of juvenile rheumatoid arthritis. Analysis of 544 cases).

Mancini, G., Carbonara, A. O., and Heremans, J. F. (1965). Immunochemistry, 2, 235 (Immunochemical quantitation of antigens by single radial immunodiffusion).

Porter, R. R. (1959). Biochem. J., 73, 119 (The hydrolysis of rabbit $\gamma$-globulin and antibodies with crystalline papain).

Torrigiani, G., Corbett, M., Lloyd, K. N., and Roitt, I. M. (1969). Raised IgC antiglobulin values in sero-negative rheumatoid arthritis. In preparation.

— and Roitt, I. M. (1967). Ann. rheum. Dis., 26, 334 (Antiglobulin factors in sera from patients with rheumatoid arthritis and normal subjects).

- (1969). J. Immunol., 102, 492 (Quantitative estimation of antibodies in different immunoglobulin classes).

Zutshi, D. W., Ansell, B. M., Bywaters, E. G. L., Epstein, W. V., Holborow, E. J., and Reading, A. (1969). Ann. rheum. Dis., 28, in the press (The FII haemagglutination test for serum antiglobulin factors in Still's disease (juvenile chronic polyarthritis)).

\section{Les facteurs élevés d'antiglobulines IgG dans la maladie de} Still

\section{RÉSUMÉ}

Les antiglobulines IgG mesurées par une technique d'immuno-adsorption quantitative étaient élevées chez tous les 26 cas de maladie de Still. Seulement deux des neuf malades classés comme inactifs montraient des taux élevés et ces deux malades avaient eu subséquemment une rechute d'une enflure du tissu cellulaire. Quatre cas actifs avaient des antiglobulines IgM mais étaient négatifs aux tests de latex et d'agglutination différentielle.
Factores antiglobulina IgG elevados en la enfermedad de
Still

\section{SUMARIO}

Las antiglobulinas IgG, medidas por la técnica de inmunoabsorción cuantitativa se elevaron en todos los 26 casos de enfermedad de Still activa. Solamente dos de nueve, clasificados como inactivos, mostraron valores elevados, y ambos han experimentado subsecuentemente recurrencia de inflamación de tejidos blandos. Cuatro casos activos acusaron antiglobulinas IgG, pero las pruebas DAT y de látex fueron negativas. 